\title{
Predatory capacity of Adalia angulifera (Coleoptera: Coccinellidae) larvae on Myzocallis coryli (Hemiptera: Aphididae) in Chile
}

\author{
Alfonso Aguilera ${ }^{1}$, Rodrigo Neculmán ${ }^{1}$, and Ramón Rebolledo ${ }^{1,2}$ \\ ${ }^{1}$ Facultad de Ciencias Agropecuarias y Forestales, Universidad de La Frontera. Temuco, Chile. Casilla 54-D, \\ Temuco, Chile. \\ ${ }^{2}$ Doctorado en Ciencias Mención Biología Celular y Molecular Aplicada, Universidad de La Frontera. \\ Temuco, Chile.
}

\begin{abstract}
A. Aguilera, R. Neculmán, and R. Rebolledo. 2014 Predatory capacity of Adalia angulifera (Coleoptera: Coccinellidae) larvae on Myzocallis coryli (Hemiptera: Aphididae) in Chile. Cien. Inv Agr. 41(1): 81-88. In La Araucanía, the filbert aphid Myzocallis coryli (Goeze) is a pest that can cause various types of damage to hazelnut (Corylus avellana L.) including reduction in nut size and nut emptiness. M. coryli can also leave hazel leaves susceptible to the fungus known as fumagina (Capnodium sp.), which causes decreased photosynthesis, particularly during the period when the tree is storing reserves for the following season. Knowledge about the natural enemies of $M$. coryli in Chile is in its early stages compared with other countries where the hazelnut crop is more extensive. Indeed, only 13 entomophagous predators have been recorded in La Araucanía thus far, including one Hemerobiidae, one Syrphidae, one Cecidomyiidae and ten Coccinellidae. Of this last family, Adalia is the best represented genus, with three species. In this study, the life cycle of the Adalia angulifera Mulsant (Coleoptera: Coccinellidae) has been ascertained. M. coryli as its food, and the ability of the larvae to prey on the same aphid is presented here. This study took place under semicontrolled laboratory and greenhouse conditions in the Region of the Araucanía, Chile. This study showed that the average predatory capacity of the A. angulifera larvae was $127.60 \pm 33.21$ specimens of $M$. coryli. For each larval instar (L), it was determined that the daily average prey was $6.8 \pm 2.45$ aphids for L I; $14.64 \pm 5.77$ aphids for L II; $42.72 \pm 17.12$ aphids for L III and $63.44 \pm 26.21$ aphids for L IV.
\end{abstract}

Key words: Biological control, Coccinellidae, control hazelnut pests, filbert aphid, hazelnut.

\section{Introduction}

The hazelnut pest Myzocallis coryli (Goeze) is a European aphid that has expanded into the rest of the world and is now found on every continent.

Received September 5, 2013. Accepted December 5, 2013. Corresponding author: ramon.rebolledo@ufrontera.cl
Its main host trees and shrubs are of the genus Corylus (C. avellana, C. colurna, C. heterophylla, C. máxima) (Blackman and Eastop, 1985). Particularly for hazelnut, $C$. avellana, it is thought that high populations of $M$. coryli cause a reduction in nut size, a lower proportion of full nuts and a greater production of honeydew. Increased honeydew production leaves the tree susceptible 
to the appearance and growth of fungi that stain the nut and soil harvest equipment (AliNiazee, 1980; 1983a).

In orchards in Oregon, USA, M. coryli has shown resistance to carbaryl caused by prolonged and consecutive use of this product to control hazelnut pests (AliNiazee, 1983b). It has also been indicated that this pest has developed resistance to common organophosphate insecticides, which has made controlling this insect difficult (Messing and AliNiazee, 1985). However, with the introduction of the Hymenopteran parasitoid Trioxys pallidus (Haliday) and the well-documented knowledge of the distribution and biology of the pest, $M$. coryli has come to be considered less important than effective biological control (AliNiazee, 1998).

In Chile, hazelnut is an expanding crop that is becoming more important as an alternative to traditional crops. It is estimated that there are more than 2,000 hectares of hazelnut in the Region of $\mathrm{La}$ Araucanía alone. In both experimental and commercial orchards, several pests have been found, both underground and on the foliage (Aguilera, 1995). Among the foliage insects, M. coryli is the most important. M. coryli is specific to the hazel tree in Chile, with average populations that range from 0.04 aphids per $\mathrm{cm}^{2}$ to 1.84 aphids per $\mathrm{cm}^{2}$, with a maximum of 9.44 per $\mathrm{cm}^{2}$; i.e., an estimated equivalent of close to 500 insects per leaf (Aguilera, 2006; Aguilera et al., 2011). This number is similar to those recorded in Oregon (Messing and AliNiazee, 1985).

Studies conducted in the Region of La Araucanía have demonstrated the presence of 13 natural entomophagous predator enemies, of which ten are in the Coccinellidae family (Aguilera and Pacheco, 1995; Aguilera et al., 2006; Aguilera et al., 2011; Aguilera and Escobar, 2012). This situation contrasts with that of Oregon, where 55 entomophagous predators have been recorded and, of these, coccinellids represent $40 \%$ (Messing and AliNiazee, 1985).
Of the coccinellid species mentioned for Oregon, Adalia bipunctata (L.) and Hippodamia convergens (Guérin-Meneville) are exotic species that are found in Chile. Widely known internationally, these species are found in hazelnuts in the south of the country. Nevertheless, in the Region of the La Araucanía, the most common species and the first to appear on hazel trees in spring is A. angulifera, a coccinellid that is native to Chile but biologically almost unknown in the country. Knowledge of the A. angulifera life cycle on $M$. coryli was provided some years ago (Aguilera et al., 2006).

With the aim of contributing background knowledge on the predatory capacity of $A$. angulifera larvae, this work was developed in La Araucanía, using M. coryli as food under laboratory and greenhouse conditions.

\section{Materials and methods}

The hazelnut $C$. avellana was used as a substrate to maintain the aphid M. coryli and its entomophagous predator A. angulifera. The insects were initially collected in spring, starting in September, in an orchard in the Araucanía. Hazelnut shoots were kept in greenhouse conditions and placed in black plastic bags, on which M. coryli were grown artificially. The aphid was later used as food for the A. angulifera to evaluate the predatory capacity of the larvae of this coccinellid.

Adult $A$. angulifera, were collected in the field and in the open air using an entomological net or an aspirator. Adult $A$. angulifera were placed in containers made of glass and transparent plastic $15 \mathrm{~cm}$ high and $5 \mathrm{~cm}$ in diameter that contained a hazelnut leaf. They were transferred in this way to the laboratory, where they were placed in other glass containers $10 \mathrm{~cm}$ high and $5 \mathrm{~cm}$ in diameter, with a hermetic lid and a hazelnut leaf infested with $M$. coryli bred in a greenhouse. Five adult A. angulifera were introduced to each of these containers to facilitate mating of the sexes. 
After copulation, each female was placed in a container with the same characteristics and conditions already described and kept there until egg laying. After noting egg laying, adults were switched to another container to prevent them from devouring their own eggs.

Once the A. angulifera eggs had hatched, the neonate larvae were kept in the same container and a fresh hazelnut leaf with filbert aphids from the greenhouse was added. The larvae stayed this way until they began to crawl onto the substrate. After they began to crawl on the substrate, each larva was placed in a Petri dish $55 \mathrm{~mm}$ in diameter containing a known number of aphids. Dishes also contained an Advantec $\mathrm{N}^{\circ} 2$ paper filter dampened on the bottom with ten drops of distilled water that was slightly sweetened.

The transfer of the larva and the aphids to their new container was performed with the aid of a $\mathrm{N}^{\mathrm{o}} 1$ brush with fine bristles. Thus they were bred in the laboratory at a minimum temperature of $17^{\circ} \mathrm{C} \pm 2.39$ and a maximum of $21^{\circ} \mathrm{C} \pm 2.47$, with a relative humidity of $60 \%$ and natural light. In this study, natural light meant $16 \mathrm{~h}$ of light and $8 \mathrm{~h}$ of dark.

Every $24 \mathrm{~h}$, the number of aphids consumed by the A. angulifera larva was determined and the number of aphids per larva was renewed, Aphid consumption was recorded every $24 \mathrm{~h}$ throughout larval development, and the moments at which molting took place was written down. By counting the predated aphids throughout the study period, the daily predation capacity of the coccinellid larvae was determined for each instar. Twenty five specimens were used for each instar, and the experiment was conducted for 59 days.

Each larval stage was considered and bred individually, using a known and constant aphid population. For each larval instar, the predation capacity was evaluated via 25 repetitions with a repeated measures design. Each repetition consisted of providing a larval stage with a pre-determined number of aphids in similar proportions of the winged and non-winged forms for $24 \mathrm{~h}$.

The data were subjected to measures of central tendency, analysis of variance (ANOVA) with repeated measures and Pearson's chi squared test, according to the aim of the study.

\section{Results and discussion}

Table 1 illustrates the total number of $M$. coryli predated by the $A$. angulifera larvae during the study period. Table 2 shows the daily average of aphids predated by each $A$. angulifera larval stage.

Of the 3,190 aphids predated by the A. angulifera larvae, the average predation was $127.60 \pm 33.21$ aphids per day, calculated over a period de 37.39 \pm 1.55 days. The first instar (L I) of the coccinellid predated the lowest number of aphids, totaling 170 aphids and a daily average of $6.8 \pm 2.45$ aphids. The fourth larval instar (L IV) of $A$. angulifera predated the most aphids, totaling 1,586 aphids with a daily average of $63.44 \pm 26.21$ aphids.

Table 1. Predation of M. coryli by Adalia angulifera larvae.

\begin{tabular}{lccc}
\hline $\begin{array}{l}\text { Total aphids } \\
\text { provided }\end{array}$ & $\begin{array}{c}\text { Total aphids } \\
\text { predated }\end{array}$ & $\begin{array}{c}\text { Average } \\
\text { predation }\end{array}$ & Range \\
\hline 6,000 & 3,190 & $127.60 \pm 33.21$ & $(53-179)$ \\
\hline
\end{tabular}

Table 2. Daily average of aphids predated by each larval stage of Adalia angulifera.

\begin{tabular}{lccc}
\hline $\begin{array}{l}\text { Larval stages } \\
\text { (L) }\end{array}$ & $\begin{array}{c}\text { Total aphids } \\
\text { predated }\end{array}$ & $\begin{array}{c}\text { Daily average of } \\
\text { aphid predated }\end{array}$ & Range \\
\hline L I & 170 & $6.80 \pm 2.45$ & $1-12$ \\
L II & 366 & $14.64 \pm 5.77$ & $3-26$ \\
L II & 1.068 & $42.72 \pm 17.12$ & $11-68$ \\
L IV & 1.586 & $63.44 \pm 26.21$ & $10-98$ \\
\hline
\end{tabular}

Figure 1 shows the total percentage of aphids predated for each larval instar of Adalia angulifera. In percentage terms (Figure 1), L I presented the lowest predation with $5.3 \%$ of the predated total. L II reached $11.5 \%$ of the predated total, while L III exceeded the second instar by $22 \%$, with $35 \%$ predation on $M$. coryli. Figure 1 illustrates that 


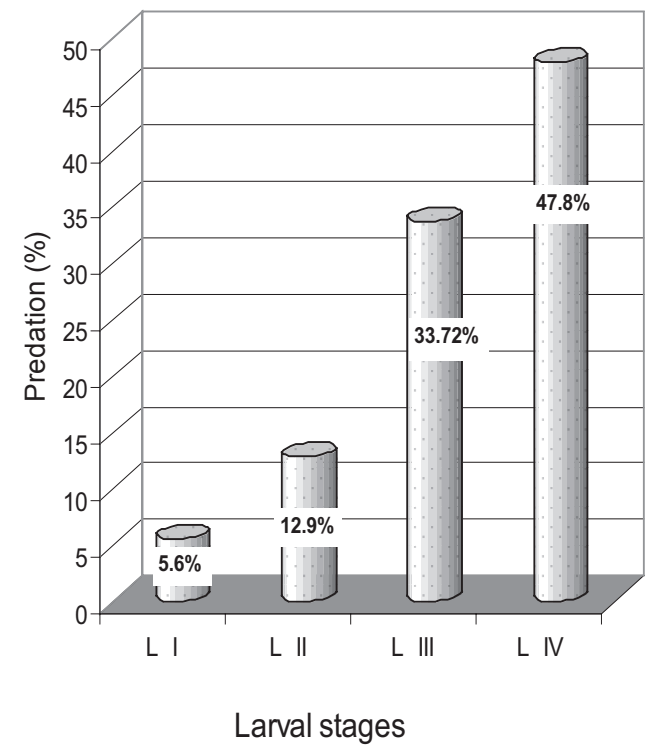

Figure 1. Percentage of $M$. coryli predated for each larval stage of $A$. angulifera.

L IV showed the highest predation percentage of $49.7 \%$, surpassing L III by $16.2 \%$.

Generally, it was observed that as a larva grew and changed stage, it also increased its predation level. This situation was reflected in the daily predation average and the total number of $M$. coryli predated.

As has been established previously, the predation of aphids by the L I larval stage of $A$. angulifera was considerably lower than the other stages. This was due, in part, to the habits of the neonate larvae. At the beginning of their development, larvae practically did not move and initially fed on their own adjacent eggs that had not yet hatched. After this first ingestion of food, the larvae began to crawl to locate their usual food. L II $A$. angulifera presented greater mobility, agility and voracity compared to L I in their search for $M$. coryli. In turn, L III was characterized as being more active than L II, with remarkably increased predatory capacity. However, when the larva was close to molting, this stage, like the previous stages, presented a period of immobility with no feeding. At the beginning of L IV, the coccinellid larva reinitiated its active period quickly and again began to feed voraciously for a longer period than in the previous stages. This situation was indicated by Aguilera et al. (2006) when they studied the life cycle of $A$. angulifera on M. coryli.

Of the total number of predated aphids, the larvae devoured a total of 1,576 winged aphids. In percentage terms, this represents $49.4 \%$ of the total population consumed, with a daily average estimated at $63.04 \pm 14.51$ winged $M$. coryli. Considering the total number of winged $M$. coryli predated by the $A$. angulifera larvae, L I was the one that predated the least, with 79 aphids, followed by L II with 158 predated aphids. L III and L IV were the instars where the most winged aphids were predated, with 524 and 815 predated units, respectively. The L III and L IV instars represent $84.96 \%$ of predation in the larval state, based on the total number of winged $M$. coryli consumed.

Table 3 shows the daily average of predated winged aphids for each larval stage of $A$. angulifera. In Figure 2, one can see the percentage of winged M. coryli predated for each larval instar of $A$. angulifera. As a percentage, L I of A. angulifera presented the least predation of winged of $M$. coryli, with $5.01 \%$. L II predated $10.02 \%$ of the total winged aphids. L III clearly fed on a greater amount of winged aphids compared to the first two stages, reaching $33.2 \%$ of predation. L IV registered the greatest predation on winged $M$. coryli with $51.7 \%$.

Table 3. Daily predation average of the larval stages of Adalia angulifera on winged $M$. coryli.

\begin{tabular}{lccc}
\hline $\begin{array}{l}\text { Larval } \\
\text { stages (L) }\end{array}$ & $\begin{array}{c}\text { Total aphids } \\
\text { predated }\end{array}$ & $\begin{array}{c}\text { Daily average of } \\
\text { aphids predated }\end{array}$ & Range \\
\hline L I & 79 & $3.16 \pm 1.41$ & $0-6$ \\
L II & 158 & $6.32 \pm 3.52$ & $1-13$ \\
L II & 524 & $20.96 \pm 9.06$ & $5-35$ \\
L IV & 1,586 & $32.60 \pm 12.21$ & $6-49$ \\
\hline
\end{tabular}

The total number of non-winged $M$. coryli predated by A. angulifera larvae was 1,614, with a daily average of $64.56 \pm 14.04$, representing $50.6 \%$ predation on the non-winged form of M. coryli. The results of predation for each larval stage of 


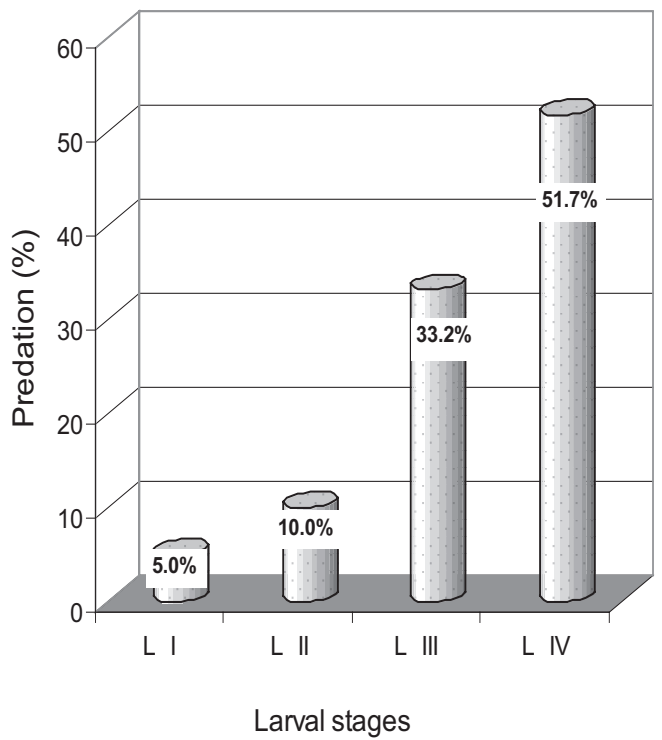

Figure 2. Percentage of $M$. coryli predated for each larval stage of $A$. angulifera.

A. angulifera on non-winged $M$. coryli appear in Table 4. According to the consumption numbers for each larval stage of A. angulifera on non-winged M. coryli (Table 4), predation increases as the larvae develop, There is an 8.5 -fold difference in the daily predation average between $\mathrm{L} \mathrm{I}$ and $\mathrm{L}$ IV, which in absolute terms is equivalent to 680 non-winged M. coryli. However, between L III and L IV, the predation difference was 1.6-fold, equivalent to 227 non-winged M. coryli.

Figure 3 illustrates the total percentage of nonwinged $M$. coryli predated by each larval instar of $A$. angulifera. As a percentage, the difference in consumption of non-winged $M$. coryli between L I and L IV was $42.2 \%$. The lowest percentage difference of predation in this case occurred between L I and L II with 7.3\%.

Table 4. Daily average of predation of Adalia angulifera larvae on non-winged $M$. coryli.

\begin{tabular}{lccc}
\hline $\begin{array}{l}\text { Larval stages } \\
\text { (L) }\end{array}$ & $\begin{array}{c}\text { Total aphids } \\
\text { predated }\end{array}$ & $\begin{array}{c}\text { Daily average of } \\
\text { aphids predated }\end{array}$ & Range \\
\hline L I & 91 & $3.16 \pm 1.76$ & $0-7$ \\
L II & 208 & $8.32 \pm 3.26$ & $1-14$ \\
L II & 544 & $21.76 \pm 9.06$ & $2-33$ \\
L IV & 771 & $30.84 \pm 14.50$ & $4-49$ \\
\hline
\end{tabular}

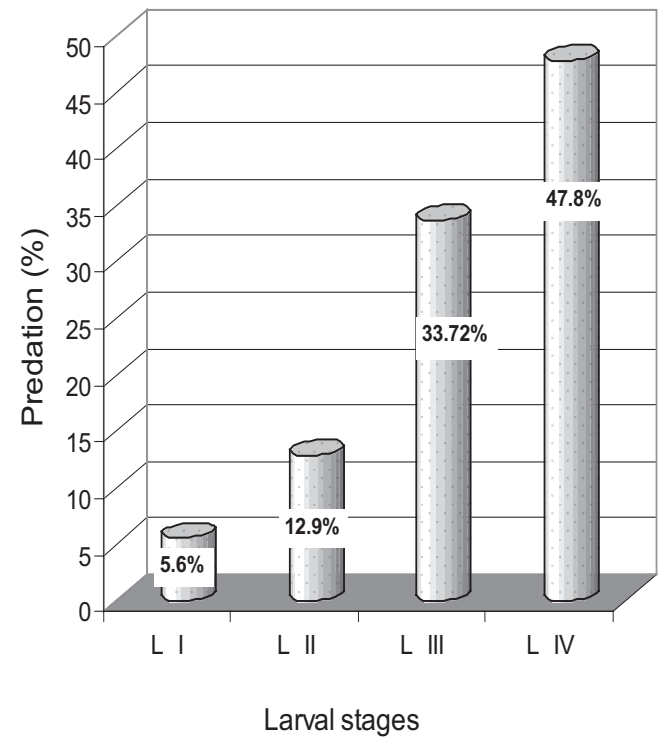

Figure 3. Percentage of non-winged $M$. coryli predated by each larval stage of $A$. angulifera.

Figure 4 shows the predation difference of A. angulifera larvae according to the form of the aphid. The $1.2 \%$ difference, with a greater number of non-winged aphids predated, is equivalent to 38 M. coryli, considering the totals from Tables 3 and 4.

A. angulifera Mulsant is a neotropical species present in Chile and Argentina (Gonzalez, 2013;

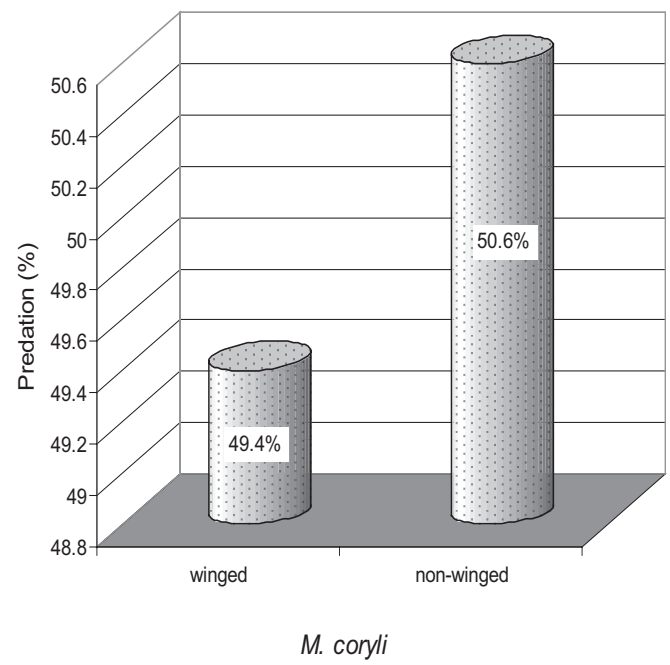

Figure 4. Predation of $A$. angulifera larvae on winged and non-winged $M$. coryli. 
Dode, 2011). It was previously known that $A$. angulifera Mulsant is a natural enemy of the aphids Acyrtosiphon kondoi Shin, A. pisum (Harris), Cavariella aegopoddii (Scop.), Metopolophium dirhodum (Walk.), Myzus ornatus Laing, and M.persicae (Sulzer), as well as the phytophagous mite Bryobia rubrioculus Sch (Prado, 1991). It has since been shown to prey upon $M$. coryli (Aguilera et al., 2006a) and its life cycle (Aguilera et al., 2006b) There are no studies that refer to the number of aphids consumed by the larvae or the adult.

In Chile, quantitative information on aphid consumption is only available for three species of Coccinellidae: Adalia bipunctata (L.), Eriopis connexa (Germar) and Neda patula (Erichson). Montes (1970) indicated that the adult A. bipunctata consume four to five aphids per day and E. connexa consume seven to ten aphids per day, further commenting that the larval state is more effective than the adult state. Zúñiga (1974) mentioned that E. connexa preyed on 180 aphids per day. Etchegaray (1982), referring to the same species, reported that the adult devoured $189.8 \pm 24.89$ aphids in 12 days and the larva, in the same period, fed on $108 \pm 4.18$ aphids. The species of aphid was not indicated in this study. In light of this information, this work is the first to consider the predation capacity of $A$. angulifera in its larval stage on the aphid M. coryli. Studies conducted with $N$. patula, on the aphids Rhopalosiphum sp., Aphis spiraecola Patch and Tuberolachnus salinus (Gmelin), determined that $N$. patula larvae differ in the number of aphids consumed according to the species. The total amount (1,178 units) was greatest when fed on $A$. spiraecola, however none of the larvae finished their development in this study and died before pupation (Aguilera,1983). When the daily and total amount of aphids predated by $A$. angulifera in this study is compared to other coccinellid species, the larvae of A. angulifera had a daily (21.85 units) and total predation capacity (3,190 units) that was greater than the larvae of E. connexa and N. patula.

However, in studies performed in Argentina by Gyenge et al. (1997) with E. connexa, the total consumption of larvae feeding on Acyrtosiphon pisum (Harris) (256 units) and Schizaphis graminun (Rondani) (641 units) was greater than feeding of $A$. angulifera on M. coryli. This indicates that the predation capacity of an aphidophagous coccinellid depends on the species of coccinellid and the species of aphid, as confirmed by several studies mentioned by Hodek (1973).

The results reported by Hodek (1973) regarding a Coccinellidae species of palearctic origin are generally consistent with what was observed with $A$. angulifera in terms of aphid consumption according to the stage of the larva. Predation capacity increases as the larva develops from egg emergence to the pupal stage.

Under the conditions of this study, the results indicate that the larvae of $A$. angulifera can be considered a good predator of the aphid M. coryli in European hazelnut.

\section{Acknowledgements}

The authors of this work are grateful to project DIUFRO DI12-0026 for providing funding. 


\title{
Resumen
}

\begin{abstract}
A. Aguilera, R. Neculmán y R. Rebolledo. 2014. Capacidad depredadora de larvas de Adalia angulifera (Coleoptera: Coccinellidae) sobre Myzocallis coryli (Hemiptera: Aphididae), en Chile. Cien. Inv Agr. 41(1): 81-88. En La Araucanía, el pulgón del avellano europeo, Myzocallis coryli (Goeze) es un áfido que puede ocasionar diversos daños al cultivo de Corylus avellana L., como reducción del tamaño de nuez, nueces vanas o favorecer en las hojas la aparición del hongo conocido como fumagina, Capnodium sp., el cual reduce la fotosíntesis, especialmente durante el periodo de acumulación de reservas del árbol para la temporada siguiente. El conocimiento sobre enemigos naturales de $M$. coryli en Chile es incipiente, comparado con otros países donde el cultivo del avellano europeo es extensivo; en efecto, para La Araucanía sólo se registran 13 entomófagos depredadores que corresponden a un Hemerobiidae, un Syrphidae, un Cecydomyiidae y diez Coccinellidae. De esta última familia, Adalia es el género más representado con tres especies. De Adalia angulifera Mulsant (Coleoptera: Coccinellidae) se ha dado a conocer su ciclo vital, con M. coryli como alimento y en esta ocasión se presenta la capacidad de depredación del estado larvario sobre el mismo áfido. El estudio se efectuó bajo condiciones semi controladas de laboratorio e invernadero en la Región de La Araucanía, Chile. Como resultado de este estudio se determinó que la capacidad de depredación del estado larvario de $A$. angulifera fue 127,60 $\pm 33,21$ ejemplares de $M$. coryli para un periodo de $37,39 \pm 1,55$ días; a su vez, para cada estadio larvario (L) se determinó que el promedio diario depredado fue para L I 6,8 $\pm 2,45$ áfidos; L II 14,64 $\pm 5,77$ áfidos; L III 42,72 $\pm 17,12$ áfidos y L IV 63,44 $\pm 26,21$ áfidos.
\end{abstract}

Palabras clave: Avellano europeo, Coccinellidae, control biológico, pulgón del avellano europeo.

\section{References}

Aguilera, A. 1983. Observaciones sobre la biología de Neda patula (Erichson) (Coleoptera: Coccinellidae) en Arica, Chile. Idesia (Arica, Chile) 7:25-38.

Aguilera, A. 1995. Control selectivo de plagas en frutales de la zona sur. Seminario de Protección Vegetal. Centro Regional de Investigación INIA Carillanca. Temuco, Chile. Serie Carillanca $\mathrm{N}^{\circ}$ 45:141- 180.

Aguilera, A. 2006. El pulgón del avellano europeo en La Araucanía. Una plaga que podría expandirse al ritmo del frutal. Tierra Adentro (Chile) 69:33-35.

Aguilera, A., and C. Pacheco. 1995. Determinación de depredadores del pulgón del avellano europeo, Myzocallis coryly (Goeze) (Homoptera: Aphididae) en la IX Región de Chile. Rev. Chilena Ent. 22:17-19.
Aguilera, A., and S. Escobar. 2012. Two new registers of coccinellid predators (Coleoptera: Coccinellidae) on filbert aphid, Myzocallis coryli (Goeze (Hemiptera: Aphididae) in Chile. $8^{\text {th }} \mathrm{In}$ ternational Congress on Hazelnut. Temuco, Chile. $100 \mathrm{pp}$.

Aguilera, A., R. Rebolledo, and C. Klein. 2006a.Coccinélidos (Coleoptera) depredadores de Myzocallis coryli (Goeze) (Hemiptera: Aphididae) en La Araucanía, Chile. Idesia (Arica, Chile) 24:13-16. Aguilera, A., R. Rebolledo, and C. Klein. 2006b. Ciclo vital de Adalia angulifera Mulsant (Coleoptera:Coccinellidae) sobre el pulgón del avellano europeo Myzocallis coryli (Goeze) (Hemiptera: Aphididae).Agricultura Técnica (Chile ) 66:312-317.

Aguilera, A., J. Guerrero, and R. Rebolledo. 2011. Plagas y enfermedades del avellano europeo en La Araucanía. Ediciones Universidad de La Frontera. Temuco, Chile. 126 pp. 
AliNiazee, M.T. 1980. Filbert insect and mite pest. Agricultural Experimental Station Oregon State University. Corvallis, Oregon. Bulletin No 643. $13 \mathrm{pp}$.

AliNiazee, M.T. 1983a. Pest status of filbert (hazelnut) insects: a 10 fear study. Canadian Entomologist (Ottawa) 115 (9): 1155-1162.

AliNiazee, M.T. 1983b. Carbaryl resistence in filbert aphid (Homoptera: Aphididae). Journal Economic Entomology 76:1002-1004.

AliNiazee, M.T. 1998. Ecology and management of hazelnut pest. Annu. Rev. Entomol. 43:395-419.

Blackman, R.L., and V.F. Eastop. 1985. Aphids on the World's Crops: An Identification Guide. John Wiley \& Sons. New York, USA. 466 pp.

Dode, M. 2011. Las species de Adalia Mulsant (Coleoptera: Coccinellidae) depositadas en la Colección de la Fundación Miguel Lillo, Tucumán, Argentina. Acta zoológica lilloana 55(1):23-32.

Etchegaray, J. 1982. Variación temporal de los estados de desarrollo de Eriopis connexa (Germar) (Coccinellidae) en Chile central. Serie Medio Ambiente 6:3-8.

González, G. 2013. Lista actualizada de Coccinellidae de Chile (on line). Available online at: http://www.
Coccinellidae.cl (Website accessed: March 18, 2013)

Gyenge, J.E., J.D. Edelstein and C.E. Salto. 1997. Efectos de la temperatura y la dieta en la biología de Eriopis connexa (Germar) (Coleoptera:Coccinellidae). An. Soc. Entomol. Brasil 27(3): 345-346.

Hodek, I. 1973. Biology of Coccinellidae. W. Junk N.V. Publishers. The Hague, The Netherlands. 290 pp.

Messing, R., and M.T. AliNiazee. 1985. Natural enemies of Myzocallis coryli (Homoptera:Aphididae) in Oregon hazelnut orchards. J. Entomological Soc. British Columbia 82:14-18.

Montes, F. 1970. Biología y morfología de Eriopis connexa (Germar, 1824) y de Adalia bipunctata (Linnaeus, 1785) (Coleoptera). Publicaciones del Centro de Estudios Entomológicos (Chile) 10:43-56.

Prado, E. 1991. Artrópodos y sus enemigos naturales asociados a plantas cultivadas en Chile. Instituto de Investigaciones Agropecuarias. Santiago, Chile. Serie Boletín Técnico No 169. 203 pp.

Zúñiga, E. 1974. Pulgones del trigo: conceptos básicos para la lucha integrada. Investigación y Progreso Agrícola (Chile) 6(2):10-15. 